\title{
Monitoring Water-Level and Water-Quality Response to Conservation Measures in the Sparta Aquifer of the Union County, Arkansas Area
}

The Union County Water Conservation Board is overseeing a conservation plan to reduce withdrawals from the Sparta aquifer and allow water levels to recover to a level that can be maintained through managed ground-water withdrawals. One major aspect of the plan is to replace ground water with surface water from the Ouachita River to supply large industrial demands in El Dorado, Arkansas. Construction of a river intake and pumping facility (fig. 1) and 5 miles of 48-inch pipeline was completed in 2002. The facility will be capable of producing 65 million gallons per day (Mgal/d). A new power plant and local industries will use the surface water in lieu of ground water from the Sparta aquifer (Burns and McDonnell, 2003).

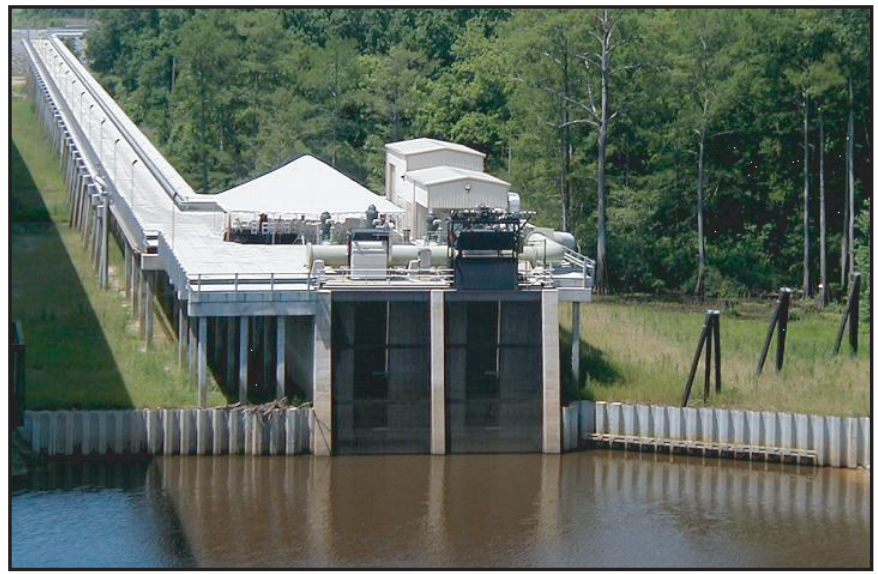

Figure 1. Ouachita River intake and pumping facility (photograph by John Czarnecki, U.S. Geological Survey).

\section{Background}

The Sparta aquifer is a primary source of ground water for industrial, municipal, and agricultural uses in southern Arkansas and northern Louisiana. In Union County, Arkansas, withdrawals from the Sparta aquifer increased since development related to the oil boom began in the early 1920's until the 1960's, resulting in water-level declines of over 250 feet in El Dorado. The water level in U.S. Geological Survey (USGS) well 17S15W18DBB1 (A in fig. 4) declined 256 feet from 1942 to 2002 (fig. 2). In addition, the chloride concentration of water within the Sparta aquifer has increased in some wells in Union County as usage has increased (Broom and others, 1984). Optimization and ground-water flow models developed by the USGS show that 1997 withdrawals of $21 \mathrm{Mgal} / \mathrm{d}$ from the Sparta aquifer in Union County must be reduced to 28 percent or about $6 \mathrm{Mgal} / \mathrm{d}$ to maintain water levels at or above the top of the Sparta Sand (Hays, 2000; McKee and Clark, 2003; McKee and others, 2004).

In 1996, the Arkansas Soil and Water Conservation Commission designated five counties in southern Arkansas, including Union County, as a "Critical Ground-Water Area" because water levels were below the top of the Sparta Sand or waterlevel declines of greater than $1 \mathrm{ft} / \mathrm{yr}$ were occurring. This encouraged Union County officials and citizens to form the Union County Water Conservation Board (UCWCB) in 1999. Under the management of the UCWCB, with cooperation from Union County, the city of El Dorado, and local industry, several water-conservation measures were implemented in Union County to reduce ground-water withdrawals (Robert Reynolds, Union County Water Conservation Board, written commun., 2003):

- The city of El Dorado installed a gray-water irrigation system on two local golf courses

- Local industries built a pipeline to allow sharing of used industrial water

- Citizens have reduced domestic and business consumption through implementation of conservation practices

- The citizens of Union County voted for a temporary 1-cent sales tax to help pay for a facility on the Ouachita River to supply surface water to local industry

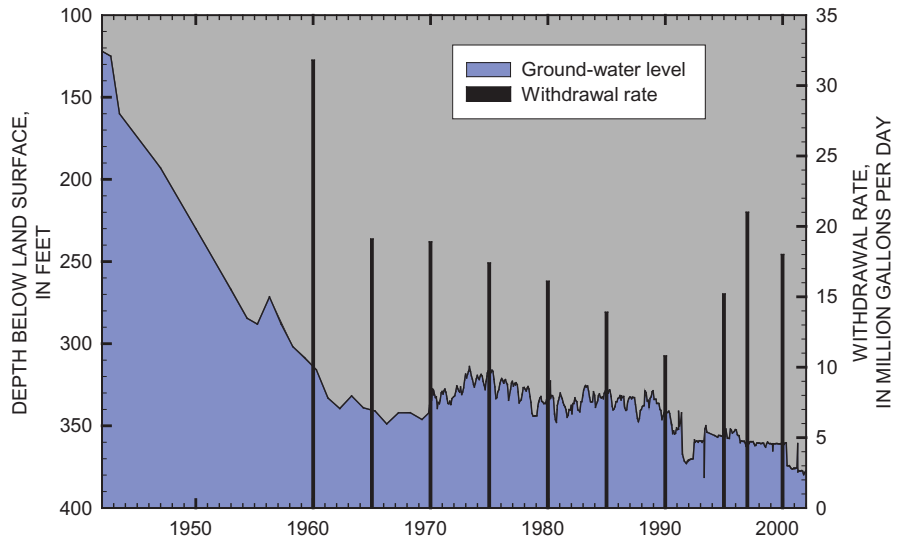

Figure 2. Ground-water levels at well A in El Dorado and total withdrawal rate from wells in Union County, Arkansas. 
The combined results of all conservation measures are expected to reduce usage from the Sparta aquifer in Union County by about $15 \mathrm{Mgal} / \mathrm{d}$. In 2002, the UCWCB received a grant from the U.S. Environmental Protection Agency to study how the conservation measures affect the ground water in the Sparta aquifer. As part of the study, the USGS is monitoring the recovery of water levels and changes in water quality in the Sparta aquifer in cooperation with the UCWCB, with assistance from Burns and McDonnell and the Union County Conservation District. Monitoring the response of the Sparta aquifer will increase understanding of the behavior of the Sparta aquifer and help planners and managers plan for future withdrawals.

\section{Sparta Aquifer}

In Union County, the Sparta aquifer comprises a sequence of sand units within the Sparta Sand, a formation of the Claiborne Group, that transmit economically important quantities of water. The sand units of the aquifer are interbedded with clay and silt units, and confined by clay units in the overlying Cook Mountain Formation and underlying Cane River Formation (fig. 3). The most productive upper and lower sand units of the Sparta aquifer in Union County are referred to as the "Green sand" and "El Dorado sand," respectively (Hays, 2000).

Recharge to the aquifer is by direct infiltration in the outcrop and by leakage from overlying alluvium and from other aquifers with higher heads (Payne, 1968). Regional direction of groundwater flow is generally to the east and south in southern
Arkansas, and to the east in northern Louisiana although large ground-water withdrawals, such as at El Dorado (fig. 4), alter the direction of flow toward the center of pumping (Broom and others, 1984; Schrader, 2004).

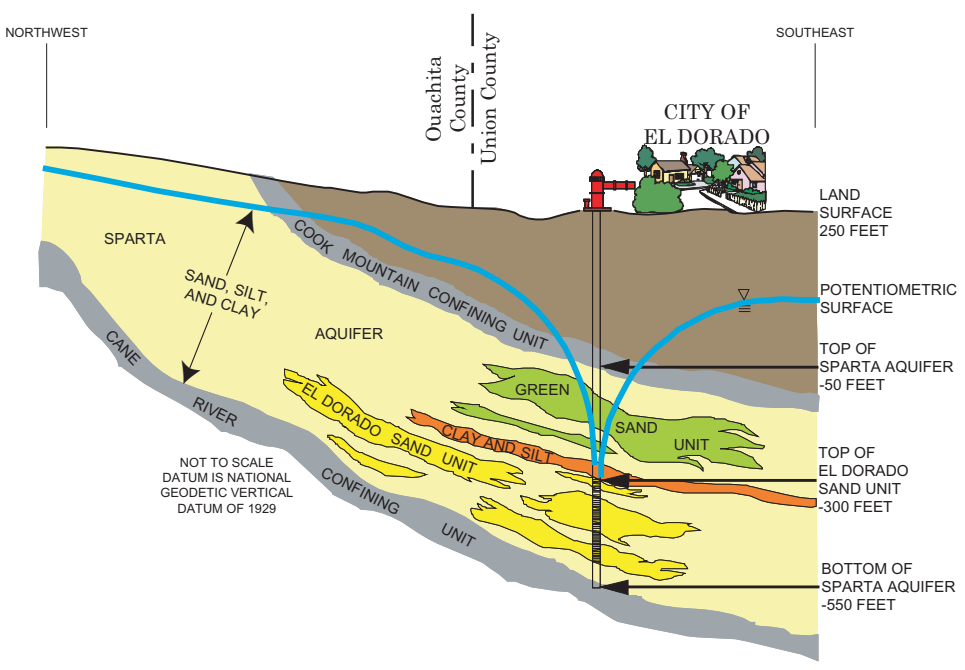

Figure 3. Conceptualized hydrogeologic section of the Sparta aquifer in southern Arkansas.

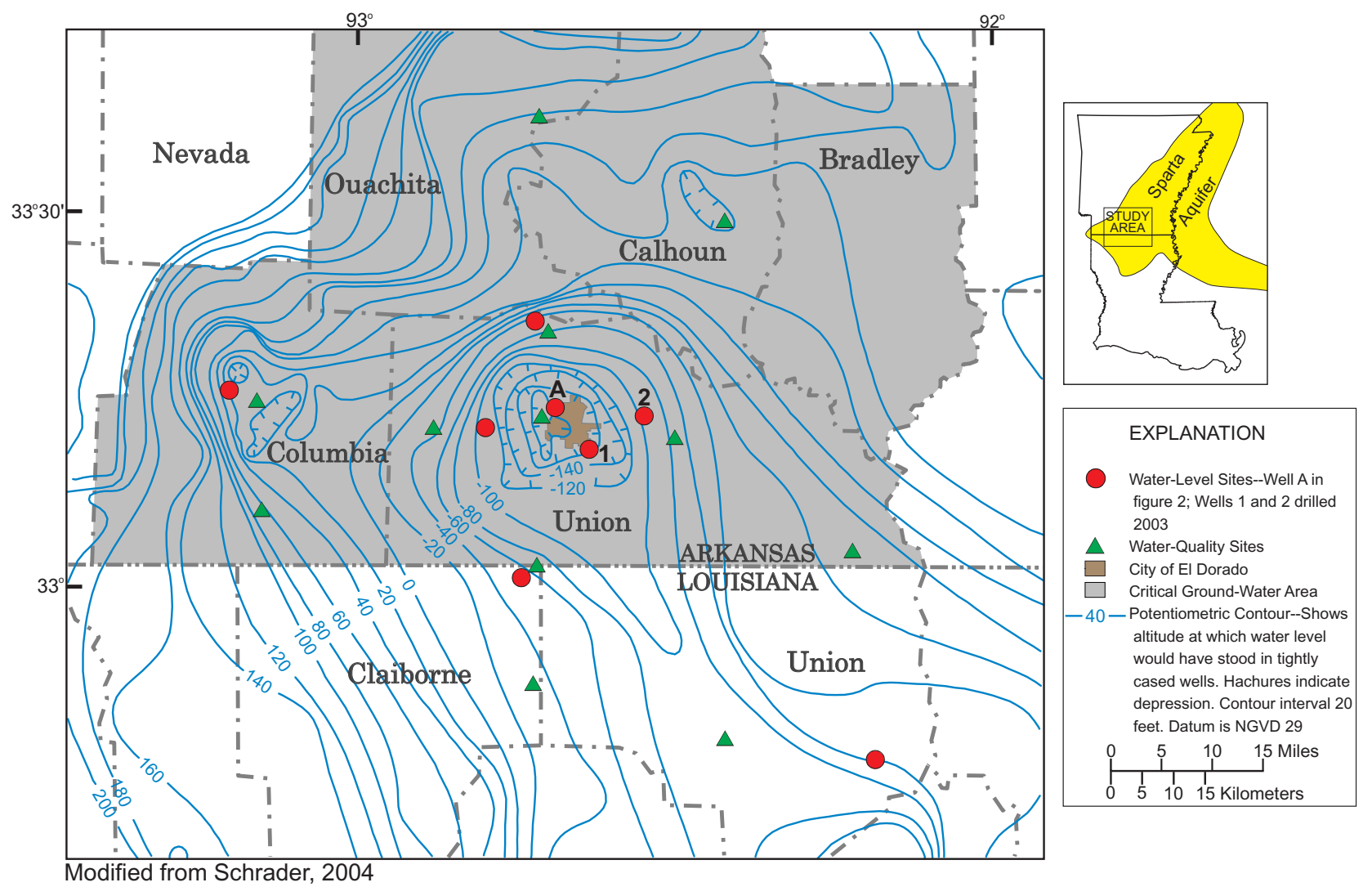

Figure 4. Location of water-level and water-quality monitoring wells and potentiometric surface of the Sparta aquifer. 


\section{Monitoring Program}

There are three major aspects of the monitoring program: characterizing the hydrogeology, monitoring water levels, and monitoring water quality. Preliminary to monitoring the water levels and water quality, the hydrogeology is characterized.

The hydrogeology is characterized to identify the major lithologic units, determine approximate depth to unit boundaries, and define the physical properties of the Sparta Sand and overlying/ underlying units. Local discontinuities and variations in Sparta aquifer unit thicknesses necessitate the gathering of this information, especially where monitor wells are located, to determine the source of ground water in the wells and to identify major sand units, the Sparta Sand, confining units, and their boundaries. This information is obtained from geophysical logs, drillers'logs, drill cuttings, and past historical records for wells. Two new wells were drilled in 2003 to gather hydrogeologic information and monitor the ground-water level (waterlevel sites 1 and 2 in fig. 4). The geophysical and lithologic logs from well 1 (fig. 5) illustrate how geophysical logs are used to interpret lithologies and their boundaries.

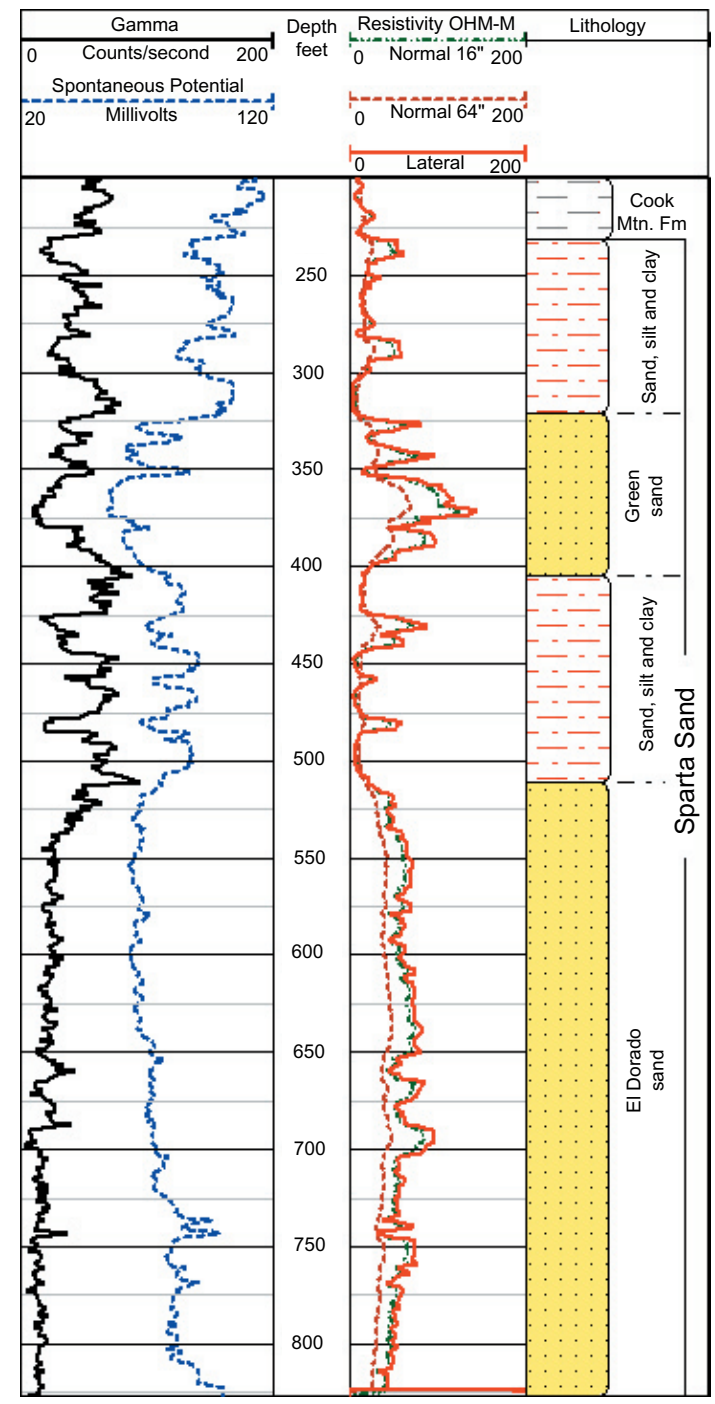

Figure 5. Geophysical and lithologic logs of well 1 in El Dorado, Arkansas.
The most observable effect of reducing ground-water withdrawals is a rise in the ground-water level elevation. This is monitored through a network of eight wells that penetrate the Sparta aquifer in Union and Columbia Counties, Arkansas, and Union and Claiborne Parishes, Louisiana (fig. 4). Where the Sparta aquifer is confined by an overlying confining layer, such as the Cook Mountain Formation, the water is under pressure and will rise in a well that penetrates the confining layer. The altitude to which the water level rises is defined as the potentiometric surface (fig. 4) (Bates and Jackson, 1980). Each well is equipped with a pressure transducer to measure water levels, a digital recorder to store the data, and a phone modem (fig. 6) to transmit water-level data to the USGS office in Little Rock, Arkansas. The water-level data are automatically processed and updated every 6 hours on the USGS web site http://ar.waterdata.usgs.gov/ (fig. 7).

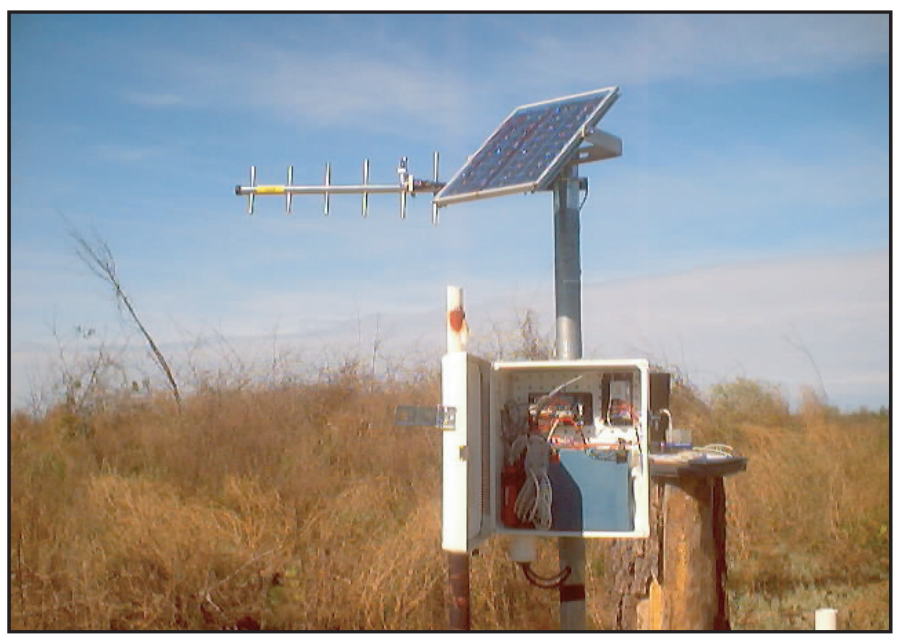

Figure 6. Water-level monitoring equipment (photograph by Ralf Montanus, U.S. Geological Survey).

Large withdrawal rates and low water levels can create conditions that induce encroachment of saltwater into the Sparta aquifer increasing the chloride concentration (Broom and others, 1984). As withdrawal rates are reduced and water levels rise because of conservation efforts, the chloride concentration is expected to decrease; therefore, the need for water-quality monitoring. Water quality is monitored through a network of 12 actively-pumped public-supply wells located near the city of El Dorado and adjacent areas in southern Arkansas and northern Louisiana (fig. 4). Water samples are collected from each well twice per year and measured for temperature and specific conductance, and analyzed for chloride concentration. 


\section{USGS 331104092380201 18S15W03DAB1 Infocenter}

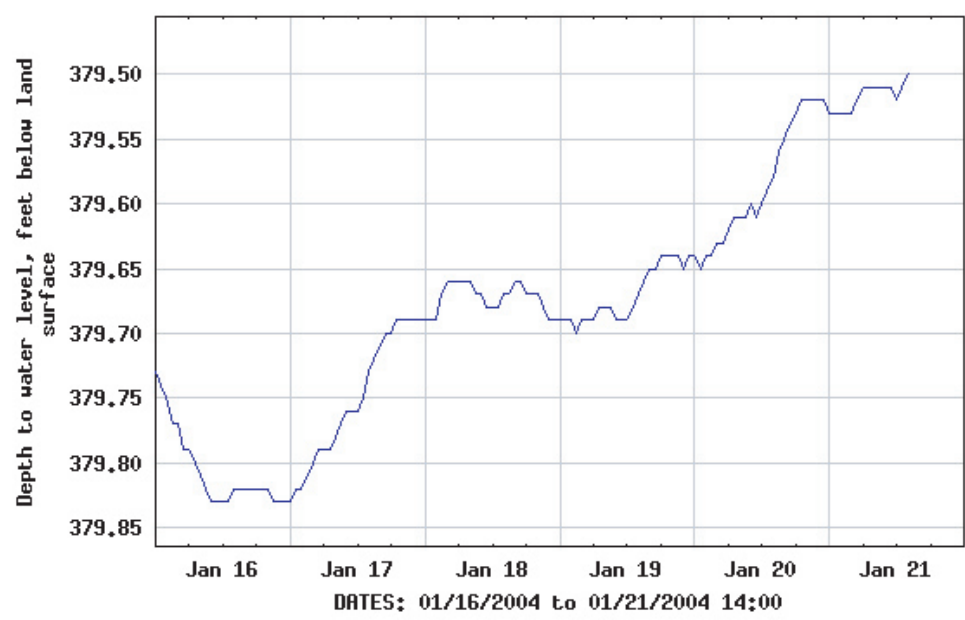

Provisional Data Subject to Revision

Figure 7. Water-level data for well 1 as displayed on U.S. Geological Survey web site.

\section{Managing for the Future}

Education, conservation, and monitoring will play key roles in managing the Sparta aquifer resource in the future. Education of government officials and citizens on the condition of the resource (fig. 8) will enable wise and informed decisions to be made. Conservation by officials, industry, and citizens will help to restore withdrawals to a sustainable level. Monitoring water levels and water quality in the Sparta aquifer will provide information on the condition of the resource to help managers plan future withdrawals and to protect the resource.

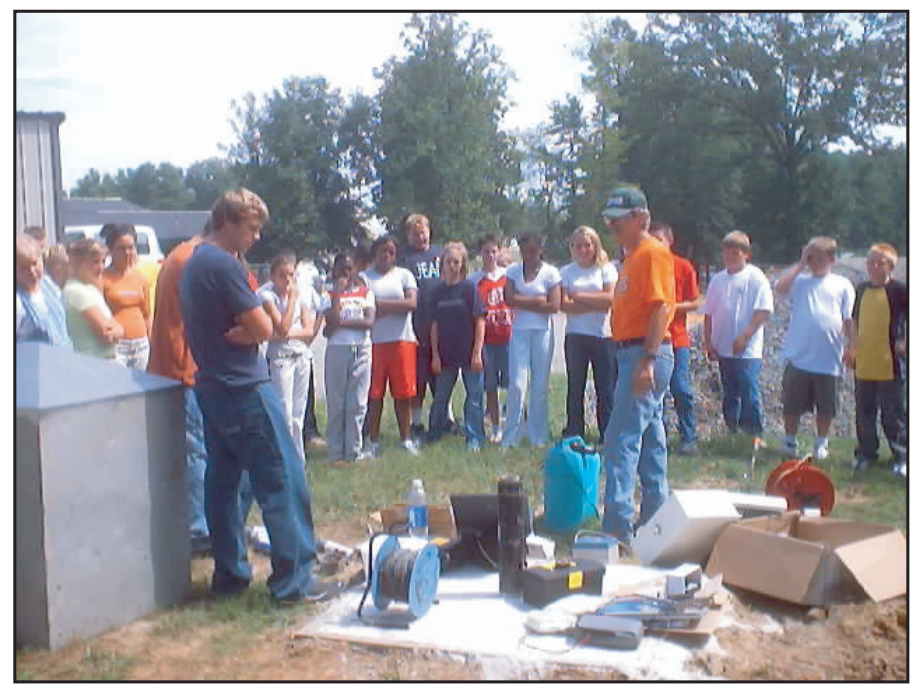

Figure 8. A U.S. Geological Survey employee demonstrates how the groundwater level is monitored in a well at a school in Union County, Arkansas (photograph by Ginger Risinger, Union County Conservation District).

\section{References}

Bates, R.L., and Jackson, J.A., eds., 1987, Glossary of geology (3d ed.): Falls Church, Va., American Geological Institute, $788 \mathrm{p}$.

Broom, M.E., Kraemer, T.F., and Bush, W.V., 1984, A reconnaissance study of saltwater contamination in the El Dorado aquifer, Union County, Arkansas: U.S. Geological Survey Water-Resources Investigations Report 84-4012, 47 p.

Burns and McDonnell, 2003, Sparta Aquifer Recovery Study, February 2003 - October 2003: 2nd Semi-Annual Report, $18 \mathrm{p}$.

Hays, P.D., 2000, Sustainable yield estimation for the Sparta aquifer in Union County, Arkansas: U.S. Geological Survey Water-Resources Investigations Report 99-4272, 17 p.

McKee, P.W., and Clark, B.R., 2003, Development and calibration of a ground-water flow model for the Sparta aquifer of southeastern Arkansas and north-central Louisiana and simulated response to withdrawals, 1998-2027: U.S. Geological Survey Water-Resources Investigations Report 03-4132, 71 p.

McKee, P.W., Clark, B.R., and Czarnecki, J.B., 2004, Conjunctive-use optimization model and sustainable-yield estimation for the Sparta aquifer of southeastern Arkansas and northcentral Louisiana: U.S. Geological Survey Water-Resources Investigations Report 03-4231, 30 p.

Payne, J.N., 1968, Hydrologic significance of the lithofacies of the Sparta Sand in Arkansas, Louisiana, Mississippi, and Texas: U.S. Geological Survey Professional Paper 569-A, $17 \mathrm{p}$.

Schrader, T.P., 2004, Status of water levels and selected waterquality conditions in the Sparta-Memphis aquifer in Arkansas and the Sparta aquifer in Louisiana, spring-summer 2001: U.S. Geological Survey Scientific Investigations Report 2004-5055, $52 \mathrm{p}$.

\section{— Daniel S. Yeatts}

Any use of trade, product, or firm names is for descriptive purposes only and does not imply endorsement by the U.S. Government.

\section{Information on technical reports and hydrologic data related to this study can be obtained from:}

District Chief

U.S. Geological Survey

401 Hardin Road

Little Rock, AR 72211

Email: dc_ar@usgs.gov

Phone: (501) 228-3600

FAX: (501) 228-3601

World Wide Web: http://ar.water.usgs.gov/ 